2014. Studies on gonadosomatic index, fecundity and hatchability of domesticated stock of asala Schizothorax richardsonii (Gray) from Nallu River of Lalitpur District. Our Nature. 12(1): 19-27. DOI: http://dx.doi.org/ 10.3126/on.v12i1.12253

\title{
Studies on Gonadosomatic Index, Fecundity and Hatchability of Domesticated Stock of Asala Schizothorax richardsonii (Gray) from Nallu River of Lalitpur District
}

\author{
Suresh Kumar Wagle \\ Fisheries Research Division, Godawari, Lalitpur, Nepal \\ Email:waglesk@yahoo.com
}

Received: 29.06.2014; Accepted: 23.09.2014

\begin{abstract}
The present work embodies studies on the reproductive capacity of captive stock of asala Schizothorax richardsonii collected from Nallu River of Lalitpur district. Gonadosomatic index (GSI) estimates ranged from $3.08 \pm 0.9 \%$ in May to $26.55 \pm 1.8 \%$ in November. Positive correlation ( $\mathrm{r}=0.667)$ was found between egg size and GSI. The egg size ( 2.7 to $2.9 \mathrm{~mm})$ in October and November was significantly $(\mathrm{P}<0.01)$ larger than the eggs measured in other months. Based on peak GSI level, S. richardsonii spawned by manual stripping in two breeding season i.e. winter (October-November) and summer (MachApril) in Godawari (1500 masl). Mean incubation period of fertilized eggs was $259 \mathrm{~h}$ and $248 \mathrm{~h}$ during winter and summer season at 14.2 to $17.5{ }^{\circ} \mathrm{C}$ and 14.5 to $15.5{ }^{\circ} \mathrm{C}$ water temperature, respectively. Percent hatching rates of eggs ranged between 38 to $90 \%$ and were not significantly different $(\mathrm{P}>0.05)$ between breeding seasons. Overripe eggs obtained during winter season breeding $(16.5 \%)$ were significantly higher $(\mathrm{P}<0.01)$ than the summer season breeding (3.6\%). This suggests that more frequent observation of the spawner is necessary during winter season for recognizing their appropriateness to ovulation.
\end{abstract}

Key words: egg size, fecundity, gonado-somatic index, overripe, ovulation

\section{Introduction}

The gonadosomatic index (GSI) is the ratio of fish gonad weight to body weight. The GSI is particularly helpful in identifying days and seasons of spawning, as the ovaries of gravid females swiftly increase in size just prior to spawning. Fecundity among egg-laying animals is the number of eggs being readied for the next spawning by a female (Royce, 1972). Fecundity appears to bear some broad relationship to the care or nurture accorded to the eggs (Lagler, 1956). It differs in different races of the same species. The measure of fecundity in fishes is a basic determinant of productivity and hence, contributes to fish culture and population dynamics. Knowledge conditions about fecundity of a fish is essential for evaluating commercial potentialities of its stock, life history, practical culture and actual management of the fishery (Islam et al., 2012).

The subfamily Schizothoracinae (family Cyprinidae), which includes Schizothorax spp and several other genera important for fisheries, distributed in the Himalayan and sub- Himalayan regions of the Indian subcontinent. The genera Schizothorax, locally known as asala, are the most 
important fish for food, economic and sport fishery point of view. Schizothorax richardsonii is one of the most dominant species in mountain waters in Nepal, indicating this fish have high adaptation capacity to reproduce and grow in cold fast flowing torrential rivers. However, this species has been overfished in the hills and Himalayas where there is a shortage of good agricultural land and of economic opportunities (Shrestha, 2002). Schizothorax fishes are characterized by slow growth, low fecundity, and late sexual maturation in their rigorous environment (Chen and Cao, 2000). These life-history characteristics further make them particularly sensitive to intense exploitation. In view of aquaculture exploitation of this species through the development of controlled breeding, important contributions to the study of maturity and spawning habit and to delimit the spawning season with different results are made by Yamada et al, 1998; Rai et al., 2002; Roy and Gurung, 2007 and Joshi et al., 1996. Systematic observations on GSI, fecundity and hatching period of captive stock of this species to establish reproduction protocol in confinement are meager. Hence, considering the economic importance of this species, an investigation on the GSI, fecundity and hatching period in relation to temperature was undertaken in the present study.

\section{Materials and methods}

Larvae with an average weight of $45 \mathrm{mg}$ of wild $S$. richardsonii was collected from Nallu River, Lalitpur district during 2006 to 2008 (Figure 1). Collected larvae were reared in raceways (flow-through system) in Fisheries Research Division (FRD), Godawari, located at 1500 masl. Fish were fed to satiation with a ration containing $35 \%$ crude protein and comprised of agricultural by-products and shrimp meal. Fish attained sexual maturity (puberty stage) in captivity after two years of rearing in raceways.

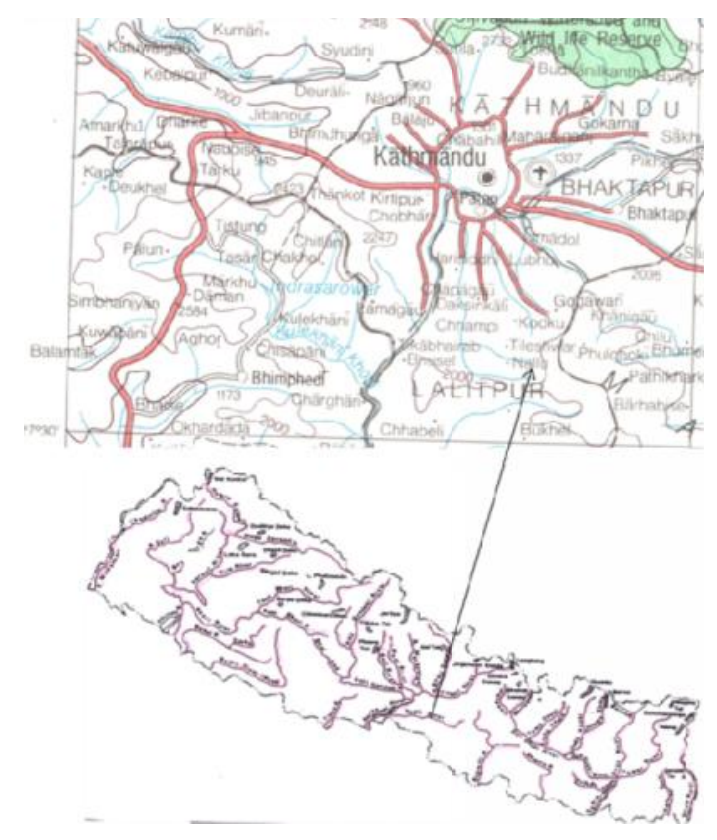

Figure 1. Location map of Nallu stream showing collection site of Schizothorax richarsonii

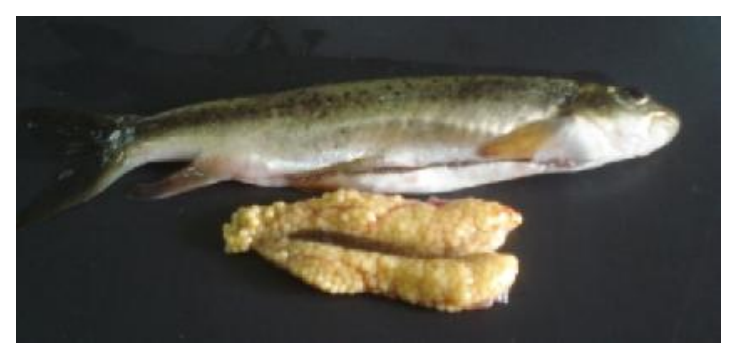

Figure 2. Mature female and ovary of Schizothorax richarsonii

Sexually matured three females in every month for the three consecutive years (2011-2013) were sacrificed to estimate gonadosomatic index (GSI). The gonadosomatic index, as a percentage 
weight of ovary to the body weight has been used as indicators of gonadal state and a maturity index of fish. After noting the length and weight of the fish, the ovaries were dissected out (Figure 2). Gonad and fish weight proportions were computed for each individuals in a monthly interval then mean of the GSI is estimated. The sexual state of the fish was measured by GSI, where:

$$
\text { GSI }=\frac{\text { weight of gonad, } g}{\text { weight of fish, } g} \times 100
$$

Egg sizes at each GSI sampling were measured using ocular micrometer under microscope. Breeding of $S$. richardsoni was carried out at FRD, Godawari on March/April and October/November following increased GSI and progress of vitellogenesis. A total of 56 and 92 female broods for summer and winter spawning with body weight ranged between 12 to $44 \mathrm{~g}$ were used, respectively. Ripe females were hand stripped and eggs were fertilized with milt pressed out from males. Milt collected in a beaker was poured over the entire surface of the eggs collected in a plastic bowl followed by mixing milt and eggs with the help of feather. After mixing the eggs and milt for about one minute water was added and gently stirred to ensure fertilization. Inseminated eggs were washed with saline water $(0.09 \%)$ for 3 to 4 times then spread over the incubation trays. Egg loaded trays were set in Atkin's incubator having continuous flow of water for aeration. The dead eggs were culled every day.

Percent overripe eggs were estimated by the proportion of number and weight of female that produced overripe eggs to that of the total number and weight of female spawned for a particular breeding season. Three gram of unfertilized eggs (before fertilization) from each spawning batch was splitted in three equal proportions and counted to estimate relative fecundity, where:

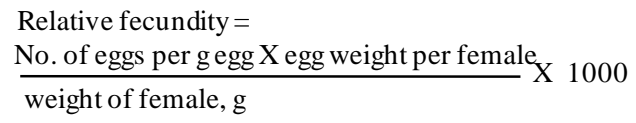

The numbers of live eggs (fertile) in each batch were estimated within $24 \mathrm{~h}$ after fertilization. Eggs were considered as live when they showed embryonic eyes and blood vessels. Hatching was considered to be successful if the yolk sac emerged from the egg envelope. Water temperature at spawning and during incubation was measured to estimate cumulative day degree temperatures. Significant differences of GSI and egg size in different months was estimated by ANOVA using Stat Graphics ver. 3.0. Egg size and fecundity regressed against GSI and body weight of female, respectively.

\section{Results}

Monthly change in the relative weight of ovaries is expressed as the gonadosomatic index (GSI). The values of GSI among months were significantly different $(\mathrm{P}<0.01)$. Gonad index was recorded low during post ovulation period in May (3.08\%) and December (4.63\%). An elevated medium index (14.9\%) for September was caused by initial vitellogenesis and it increases steadily (26.5\%) until November when mature females appear in full ripeness. A slight 
increase of the index for April (12.9\%) was also found to trigger summer spawning. The lowest GSI during May and December was the indication of ovaries was in the spent condition (Table 1).

Table 1. Monthwise mean ( \pm standard deviation, SD) gonadosomatic index (GSI) and corresponding egg size (mm) of Schizothorax richardsonii under captive condition at Godawari, Nepal

\begin{tabular}{lcc}
\hline Month & GSI, $\% \pm$ SD & Egg size, $\mathrm{mm} \pm$ SD \\
\hline January & $03.60 \pm 0.36$ & $0.84 \pm 0.10$ \\
February & $03.19 \pm 1.24$ & $0.96 \pm 0.34$ \\
March & $08.69 \pm 2.46$ & $1.01 \pm 0.40$ \\
April & $12.92 \pm 2.64$ & $1.23 \pm 0.46$ \\
May & $03.08 \pm 0.96$ & $0.49 \pm 0.27$ \\
June & $06.76 \pm 2.18$ & $0.72 \pm 0.24$ \\
July & $07.05 \pm 1.52$ & $0.75 \pm 0.28$ \\
August & $09.65 \pm 2.03$ & $1.16 \pm 0.34$ \\
September & $14.90 \pm 2.10$ & $1.64 \pm 0.53$ \\
October & $24.41 \pm 2.69$ & $2.74 \pm 0.40$ \\
November & $26.55 \pm 1.79$ & $2.89 \pm 0.24$ \\
December & $04.63 \pm 1.97$ & $0.41 \pm 0.13$ \\
\hline
\end{tabular}

The average weight of ovary ranged from a minimum value of $5.0 \mathrm{~g}$ in $12.3 \mathrm{~cm}$ average fish length to a maximum value of $16.2 \mathrm{~g}$ in $20.8 \mathrm{~cm}$ average length. A straight line was observed when ovary weight (OW) was regressed against fish length (Figure 3). The regression equation estimated was $\mathrm{OW}$ $=1.0416 \mathrm{TL}-5.9356$ and the value of correlation coefficient (r) of equation was 0.809 .

Mean egg size (diameter) of $S$. richardsonii in different months was also significantly different $(\mathrm{P}<0.01)$. Smaller eggs were obtained during May $(0.46 \pm 0.2$ $\mathrm{mm})$ and December $(0.41 \pm 0.1 \mathrm{~mm})$, post ovulation period of summer and winter spawning, respectively (Table 1). Egg size increased with the progress of vitellogenesis and reached the maximum during spawning seasons, April $(1.23 \mathrm{~mm})$ and November $(2.9 \mathrm{~mm})$. A moderate correlation $\left(\mathrm{R}^{2}=\right.$ 0.667) was estimated between GSI and corresponding egg size of $S$. richardsonii (Figure 4).

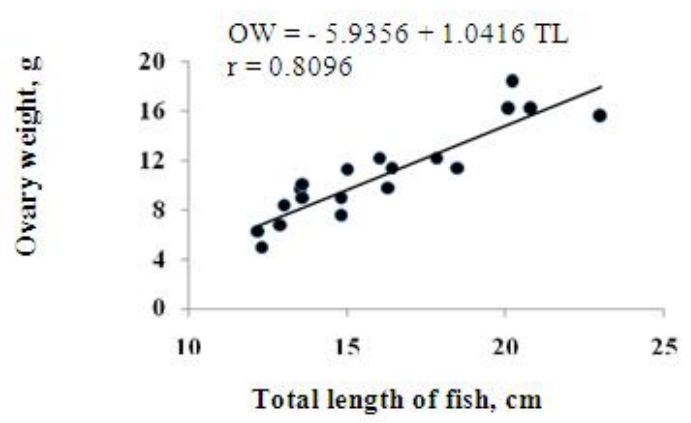

Figure 3. Relationship between ovary length and total length of Schizothorax richardsonii

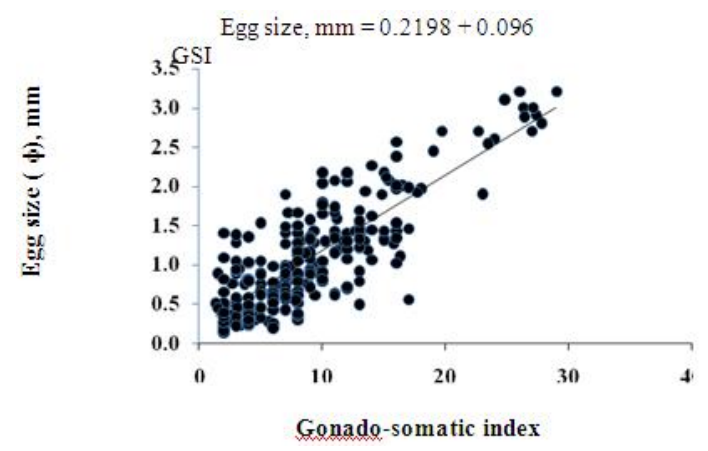

Figure 4. Relationship between egg size (diameter, $\mathrm{mm}$ ) and gonado-somatic index (GSI) of Schzothorax richardsonii

Relative fecundity $(\mathrm{F})$ defined as average egg production per $\mathrm{kg}$ female ranged from 
6294 to 67083 in fishes with weight ranged between 12 to $44 \mathrm{~g}$. Although absolute fecundity was high in heavier fish, the relative fecundity decreased with increase in body weight of fish (Figure 5). The usual method of relating fecundity to weight was employed to give the following relation: Fecundity $(\mathrm{F})=29.18 \mathrm{~W}^{2}-2380 \mathrm{~W}+$ 65132. The correlation coefficient of 0.306 indicates a moderate relationship between the fish weight and fecundity (Figure 5).

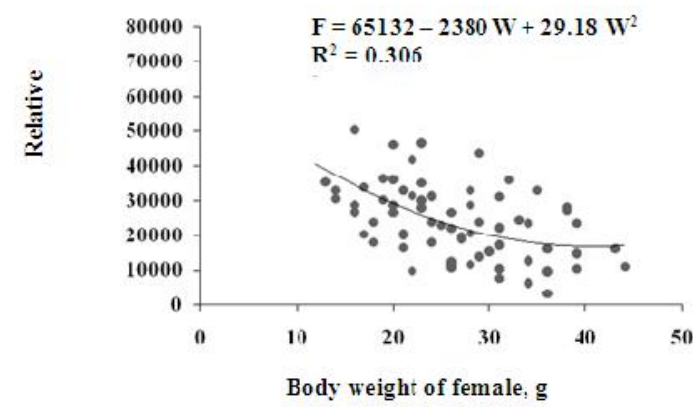

Figure 5. Relationship between Relative fecundity (number of eggs per $\mathrm{kg}$ ) and body weight of female Schizothorax richardsonii

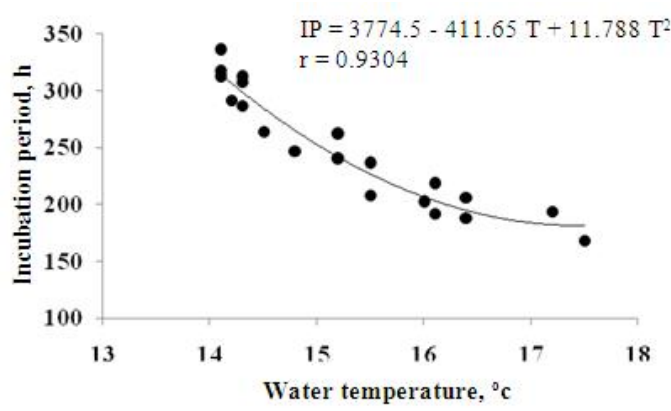

Figure 6. Relationship between water temperature and the duration of incubation period of Schizothorax richardsonii egg

Captive stocks of $S$. richardsonii spawned by manually stripping in two consecutive breeding season; OctoberNovember and March-April at Godawari (1500 masl) during the years 20011 to 2013.
Water temperature varied between 14.2 to $17.5{ }^{\circ} \mathrm{C}$ and 14.5 to $15.5^{\circ} \mathrm{C}$ during winter and summer season spawning, respectively. Mean incubation period (IP) of fertilized eggs was $259 \mathrm{~h}$ and $248 \mathrm{~h}$ during winter and summer season breeding, respectively, and the corresponding hatching rate (HR) was $68.8 \%$ and $67.7 \%$ (Table 2). Hatching rate varied greatly among different batches of spawners within each spawning season. The range of hatching rate was $38-90 \%$ in winter and $48-84 \%$ in summer. Both the IP and HR between breeding seasons of $S$. richardsoni was not significantly different $(\mathrm{P}>0.05)$. However, strong negative correlation was found between water temperature and IP and HR. At low temperature these indicators had high value and as the temperature increases the IP declined with polynomial function while HR declined linearly (Figure 6 and 7).

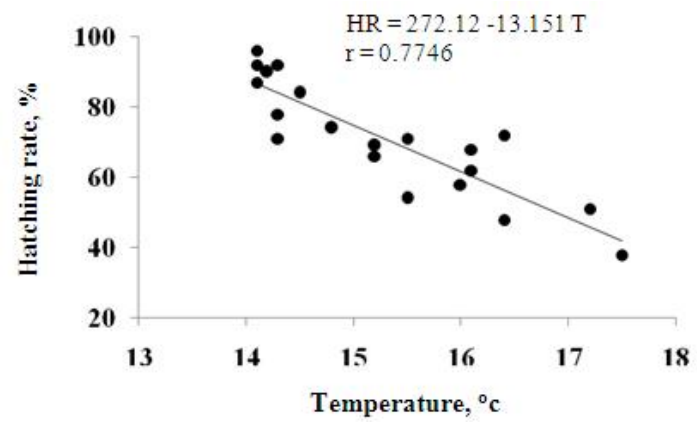

Figure 7. Relationship between water temperature and hatching rate fertilized eggs of Schizothorax richardsonii

Spawning activity was completed within 11 days in summer breeding (March-April) while it took 21 days in winter breeding (October-November) with low intensity of brood inspection for their readiness to spawn. The duration of spawning activity was judged by the availability of ripe and readiness of potential spawner for ovulation 
through inspection of each female at every 4-5 days interval during the breeding Table 2. Spawning season wise comparison of over mature eggs, incubation period and hatching rate of fertile eggs of S. richardsinii

\begin{tabular}{cccccc}
\hline $\begin{array}{l}\text { Spawning } \\
\text { season }\end{array}$ & Month & $\begin{array}{c}\text { Temperature } \\
\text { range, }{ }^{\circ} \mathrm{C}(\text { mean })\end{array}$ & $\begin{array}{c}\text { Percent over } \\
\text { mature eggs } \\
\pm \mathrm{SD}\end{array}$ & $\begin{array}{c}\text { Incubation } \\
\text { period, } \mathrm{h} \\
\pm \mathrm{SD}\end{array}$ & $\begin{array}{c}\text { Percent } \\
\text { hatching rate } \\
\pm \mathrm{SD}\end{array}$ \\
\hline \multirow{2}{*}{ Winter } & Oct-Nov & $14.2-17.5(15.4)$ & $16.5 \pm 7.9^{*}$ & $259 \pm 66$ & $68.8 \pm 29.8$ \\
Summer & Mar-Apr & $14.5-15.5(15.2)$ & $3.6 \pm 0.6$ & $248 \pm 14$ & $67.7 \pm 18.2$ \\
\hline
\end{tabular}

* denotes significantly different within column at $\alpha 0.05$

season. Despite of routine checking of spawner, $16.5 \%$ of the eggs ovulated in winter season breeding were found overripe while summer spawning had significantly low percentage of overripe eggs $(3.6 \%)$ (Table 2).

\section{Discussion}

The present attempt is a preliminary quantitative study aimed at finding a relationship between gonad maturity and different months of the year, and the rate of ovulation with the size of fish. Monthly estimation of GSI revealed that the captive populations of mature $S$. richardsonii become ripe for spawning for the two consecutive seasons October to November and March to April. Several previous studies on GSI and histology of ovary reported that this fish spawn twice in a year (Shrestha and Khanna, 1976; Agrawal, 1999; Agrawal et al., 2001). External factors of environment such as rainfall, water surface temperature, $\mathrm{pH}$, hormone secretion, turbidity are also equally important to identify appropriate timing of breeding of Schizothorax spp in Nepal (Shrestha, 1978). Deviation in breeding season of this species might have attributed with changes in these factors that breeding occurs late August to October and January-February in
Bhilangana River, Garhwal India (Agrawal, 1999).

Fecundity depends equally on the body length as well as on the weight of the fish (Raina, 1997). In the present study relative fecundity of S. richardsonii varied greatly among different body weight fishes and a negative correlation was established between the fish weight and fecundity (Figure 5). This contrasts to the findings of other studies; an increase in body weight has accompanied by an improvement in egg number of $S$. richardsonii of Kasmir, India (Gandotra et al., 2009) and rainbow trout (Gall, 1975; Mulmi et al., 2010). Thorpe et al. (1984) have advocated that egg production varies among individuals and populations of fish species due to differences in age and size. According to Kraus et al. (2000) the fecundity of individual fish of the same size drawn from the same spawning population within the same spawning season shows considerable deviation due to differential growth of gonads. According to Nikolsky (1963), the food consumed by the fish plays an important role not only in the fecundity but also the quality of the egg and their fertilization. Individual physiology of the fish and their surroundings may be the controlling factors for variation in fecundity among fishes of same size (Hossain et al., 
1997). The variation in fecundity among individual fish and different results with regard to fecundity found in this study may be due to the difference in the length of fish and also due to different geographical region having different climate, annual temperature and difference in the availability of food which affect the individual physiology of the fish. However, in this study a strong positive correlation was established between ovary weight as indirect indicator of fecundity and length of fish. The relationship between ovary weight and fish length of this species is in agreement with the findings of Gandotra et al. (2009), Gandotra et al. (2008) and Rahman and Haque (2008).

Present study revealed that spawning duration in summer was shorter than the winter spawning and the observations are in confirmation to the findings of Agrawal et al. (2001). In the present study $16.5 \%$ of the eggs ovulated in winter season breeding were found overripe while summer spawning had significantly low percentage of over ripe eggs (Table 2). An increase in over maturity of female of $S$. richardsonii might have been the cause of differences in length of spawning duration. This suggests that more frequent inspection of female is important during spawning season to avoid wastes of eggs owing to overripe condition, more specifically in winter season having relatively long spawning period for recognizing their appropriateness to ovulation.

The incubation period is dependent on the water temperature as it gets reduced at higher water temperature. In this study incubation period estimated was 248 to 259 $\mathrm{h}$ at 14.2 to $17.5^{\circ} \mathrm{c}$ water temperature which is in order with the incubation period recorded between 264 to $287 \mathrm{~h}$ at 10 to 14.7 ${ }^{\circ} \mathrm{C}$ water temperature in Garhwal Himalaya (Agrawal et al., 2001).

Single layer of fertilized eggs were placed in wooden tray in flow throw hatchery and high rate of hatching (38-90\%) was estimated in this study. The results are in agreement with the findings of Agrawal et al. (2001). They compared the hatching rate of $S$. richardsonii in flow throw, stagnant water and portable jar conditions in Tehri Garhwal, India and found that hatching rates were high in flow throw system. However, differences in hatching rate observed in the present study did not corroborate with the higher hatching rate observed in October/November (>50\%) than in February/March $(<25 \%)$ breeding of Schizothorax sp in Trishuli (Joshi et al., 1996) and in Kali Gandaki Fish Hatchery (Baidya et al., 2011).

Thus, the present research findings clearly depict that the Schizothorax richardsonii become ready to spawn twice in a year in captive conditions. Elevated GSI accompanied with larger egg size found during March/April and October/November indicating the trigger of spawning episode during these periods of a year. Regression analysis revealed higher degree of correlation $(\mathrm{r}=0.81)$ between ovary weight and fish length than the correlation between relative fecundity and body weight $(r=0.30)$ indicating the dependence of fecundity more on fish length. The result of controlled breeding and incubation of Schizothorax richardsonii in a running water system gave 
mean hatching of $68.8 \%$ in winter and $67.7 \%$ in summer spawning. However, large variation in fecundity and hatching rates among spawning batches and within spawning season found in this study stipulate for the need of nutritional studies to improve fecundity and regulation of rearing environment particularly the water temperature for enhancing hatching rate of this species.

\section{Acknowledgements}

This study was supported by the funding obtained by Nepal Agricultural Research Council (NARC). Authors are grateful to staffs of Fisheries Research Division, Godawari for their support in GSI estimation and breeding activity of asala.

\section{References}

Agrawal, N. K. 1999. Annual project report for the year 1999. ICAR Project, Department of Zoology, HNB Garhwal University Campus, Badshahithaul. pp. 33.

Agrawal, N. K., B. L. Thapaliyal and U. S. Rawat. 2001. Artificial breeding of a snowtrout, Schizothorax richardsonii, inhabiting th Bhilangana River of Garhwal Himalaya. J. Inland Fish. Soc. India, 33(1): 77-80.

Baidya, A. P., J. D. Bista and T. B. Gurung. 2011. Domestication and breeding status of some fishes in Nepal. In: Wagle S.K., T. B. Gurung and N. Pradhan (eds.) Proceedings of Workshop on Indigenous Fish Stock and Livelihood in Nepal: 55-71.

Chen, Y. F., W. X. Cao. 2000. Schizothoracinae. In Yue P.Q. (ed.) Fauna sinica osteicthtyes cypriniformes III. Beijing: Science Press, pp. 273388. (in Chinese).

Gall, G. A. E. 1975. Genetics of reproduction in domesticated rainbow trout. J. Anim. Sci. 40:1928.

Gandotra, R., R. Shankar and D. Singh. 2009. Studies on fecundity of snow trout Schizothorax richardsonii (Gray) from the lotic bodies of Rajouri district (J\&K). Current World Environment, 4(1): 127-132.
Gandotra, R., S. Ahmed, R. Shanker and S. Sagar. 2008. Fecundity in a hill stream minor carp Barilius vagra (Ham.) from Jhajjar stream, Jammu (J\&K). J. Aqua. Biol., 23(1): 92-96.

Hossain, M. A., S. Parween and M. A. Rahman. 1997 Fecundity of Nandus nandus (Ham.-Buch.). J. Biosc., 5: 305-307.

Islam, M. R., N. Sultana, M. B. Hossain and S. Mondal. 2012. Estimation of Fecundity and Gonadosomatic Index (GSI) of Gangetic Whiting, Sillaginopsis panijus (Hamilton, 1822) from the Meghna River Estuary, Bangladesh. World Appl. Sci. J., 17(10): 1253-1260.

Joshi, P. L., M. Igarashi and A. P. Nepal. 1996. Influence of breeding periods on the hatchability of asala (Schizothorax plagiostomus). In: B. S. Kuwar and H. R. Shrestha (eds.) Proceedings of the $1^{\text {st }}$ National Workshop on Livestock and Fisheries Research in Nepal. NASRI, NARC: 98 103.

Kraus, G., A. Muller, K. Trella and F. W. Koster. 2000. Fecundity of Batic cod: Temporal and spatial variation. J. Fish. Biol., 56: 1327-1341. http://dx.doi.org/10.1111/j.10958649.2000.tb02146.x

Lagler, K.F., 1956. Enumeration of fish eggs. In: Freshwater Fishery Biology. 2 ed. pp: 106-110 W.M.C. Brown Company, Dubuque.

Mulmi, R. M., N. Pradhan, S. K. Wagle and M. KC. 2010. Breeding performance of different age cohort $\left(1^{+}\right.$and $2^{+}$year) rainbow trout (Oncorhynchus mykiss) in private hatchery at Tatopani, Sindhupalchok. Annual Technical Report. Fisheries Research Division, Godawari, Lalitpur: 26-30.

Nikolsky, G. V. 1963. The Ecology of fishes. London Academic Press, New York: 1-352.

Rahman, M. A. and M. M. Haque. 2008. Gonadal development of Gadusia chapra (HamiltonBuchanan) from Rajdhala reservoir, Bangladesh. J.Inland Fish. Soc. India. 40(1): 10-15.

Rai, A.K., S. R. Basnet, A. P. Nepal, R. M. Mulmi and N. K. Roy. 2002. Potential of asla and trout culture for economic enhancement of the people in the Hilly Region of Nepal . In: T. Petr and D. B. Swar (eds.) Cold Water Fisheries in the TransHimalayan Countries. FAO Fisheries Technical Paper No. 431, Rome.

Raina, H. S. 1997. Observations on the fecundity and spawning behaviors of Schizothorax esocinus Heckle from Dal lake, Kashmir. Ind. J. fish, 24:201-203. 
Suresh Kumar Wagle / Our Nature (2014), 12(1): 19-27.

Royce, W.F., 1972. Introduction to the Fishery Science. Academic Press, New York. pp: 251.

Roy, N. K. and T. B. Gurung. 2007. Feeding trial on Asala (Schizothorax sp.) in Godawari. Annual Technical Report 2007, Fisheries Research Division, Godawari, Lalitpur.

Shrestha, T. K. 1978. A new report on induced spawning in Nepalese hill-stream trout Schizothorax plagiostomus (Heckel). J. Inst. Sc. 1: 171176.

Shrestha, T. K. and S. S. Khanna, 1976. Histology and seasonal changes in the testes of a hill-stream fish
Schizothorax plagiostomus. Z. microskop. anat. Forsch. Leipzig 90(4): 749-761.

Thorpe, J. E., M. S. Miles and D. S. Keau. 1984. Development rate, fecundity and egg size in Atlantic salmon, Salmo salar L. Aquaculture, 43: 299-305. http://dx.doi.org/10.1016/0044-8486(84) 90030-9

Yamada, T., K. Masuda, S. K. Shrestha and M. P. Thapaliya. 1998. Study of growth and fecundity of buchche asala (Schizothorax plagiostomus) and Chuchche asala (Schizothorax progastus). Annual Technical Report. Fisheries Research Centre, Trishuli,Nepal:26-36. 